Krzysztof Walczak ำ https://orcid.org/0000-0003-1383-6993/

Uniwersytet Warszawski

\title{
„OPTYMALIZACJA” KOSZTÓW ZATRUDNIENIA W ADMINISTRACJI RZĄDOWEJ
}

\begin{abstract}
"Optimization" of employment costs in government administration

The purpose of this article is to analyze the planned optimalization of employment costs in government administration. The reason foar introducing these actions is the threat to public finances related to coronavirus. The Act provides for two forms of reduction of employment costs. The first is collective redundancies and the second is the suspension of employees' rights. The author recognize the legitimacy of actions aimed at reducing the public finance deficyt. However, he critically refers to the detailed provisions contained in the Act. This applies primarily to the way of dismissing employees from work, which deprives them of any protection and support for both trade unions and employment administration.
\end{abstract}

Słowa kluczowe: koronawirus, pracownik, związki zawodowe, administracja rządowa, zwolnienia grupowe, zawieszenie prawa zakładowego

Keywords: coronavirus, employee, trade unions, goverment administration, collective redundancies, suspension of company's sources of labour law

ASJC: 1410, JEL: J5

\section{Wprowadzenie}

Ustawa z dnia 16 kwietnia 2020 roku o szczególnych instrumentach wsparcia w związku z rozprzestrzenianiem się wirusa SARS-CoV-2 (Dz.U. 2020, poz. 695 ze zm.), która weszła w życie 18 kwietnia 2020 roku, znowelizowała ustawę z dnia 2 marca 2020 roku o szczególnych rozwiązaniach związanych z zapobieganiem, przeciwdziałaniem i zwalczaniem COVID-19, innych chorób zakaźnych oraz wywołanych nimi sytuacji kryzysowych (Dz.U. 2020, poz. 374 ze zm., dalej: specustawa COVID-19). Wśród licznych uregulowań ustawa z dnia 16 kwietnia 2020 roku wprowadziła możliwość przeprowadzenia bardzo drastycznych zwolnień grupowych w administracji rządowej z pominięciem powszechnie obowiązujących przepisów, w tym zwłaszcza ustawy z dnia 13 marca 2003 roku 
o szczególnych zasadach rozwiązywania z pracownikami stosunków pracy z przyczyn niedotyczących pracowników (Dz.U. 2018, poz. 1969 tekst jedn., dalej:ZwolGrupU)ํ. Uznając zasadność dbania o dobro finansów publicznych, wydaje się jednak, że jej postanowienia mogą, jeżeli oczywiście delegacja ustawowa zostanie wykorzystana, stanowić podstawę do dokonania bardzo głębokiej i niekontrolowanej wymiany kadr w administracji rządowej, co może stanowić zagrożenie dla efektywności i apolityczności funkcjonowania „aparatu państwowego". W tym kontekście trudno bowiem uznać za wystarczające stwierdzenie, że proces ten będzie uwzględniał konieczność zapewnienia prawidłowego realizowania zadań administracji rządowej. I właśnie analiza przepisów ustawy ze wskazaniem wątpliwości nie tylko legislacyjnych, ale również praktycznych jest przedmiotem niniejszej publikacji.

\section{Założenia wprowadzenia specjalnych mechanizmów związanych $\mathrm{z}$ restrukturyzacją zatrudnienia $\mathbf{w}$ administracji rządowej}

Truizmem jest stwierdzenie, że pandemia koronawirusa jest wydarzeniem bezprecedensowym, a jeżeli będzie się przeciągała, może stanowić zagrożenie zarówno dla samej gospodarki, jak i dla funkcjonowania państwa jako takiego. Z pewnością wszelkie działania mające na celu zminimalizowanie wynikającego z niej zagrożenia dla finansów publicznych państwa należy uznać za zasadne. Dlatego też sama aksjologia działań zawarta $\mathrm{w}$ art. 15zzzzzo specustawy COVID-19 nie powinna wydawać się kontrowersyjna, jednakże już planowany sposób ich realizacji budzi istotne zastrzeżenia. I tak we wskazanym wyżej artykule wskazuje się, że działania będą podejmowane w przypadku gdy negatywne skutki gospodarcze COVID-19 spowodowują stan zagrożenia dla finansów publicznych państwa, w szczególności wyższy od zakładanego w ustawie budżetowej wzrost deficytu budżetu państwa lub państwowego długu publicznego. Wydaje się, że delegacja ustawowa do przewidzianych w dalszej części radykalnych działań w stosunku do zatrudnionych powinna być konkretna i jednoznaczna. Zawarcie w tym przepisie zwrotu otwartego „w szczególności” oznacza, że Rada Ministrów będzie w sposób arbitralny miała możliwość skorzystania z nadanych jej uprawnień, nie ulega bowiem wątpliwości, że od momentu wprowadzenia tak zwanych tarcz antykryzysowych ich realizacja stanowi zagrożenia dla finansów publicznych. Tak więc racjonalne byłoby jednoznacznie przesądzenie, w którym momencie Rada Ministrów ma podjąć stosowne działanie, bez opisywania procedury, w jaki sposób ma dochodzić do wydania aktów prawnych, co ma czysto techniczny charakter (wniosek Szefa Kancelarii Prezesa Rady Ministrów

${ }^{1}$ Przy czym należy wskazać, że mimo iż ustawa ta stanowi wdrożenie do polskiego porządku prawnego dyrektywy 98/59/WE z dnia 20 lipca 1998 roku w sprawie zbliżenia ustawodawstw państw członkowskich odnoszących się do zwolnień grupowych (Dz.Urz. WE L 1998, nr 225, dalej: dyrektywa 98/59), to wyłączenie jej stosowania samo w sobie nie stanowi naruszenia prawa europejskiego. Jak wskazuje bowiem jej art. 1 ust. 2 pkt 2, nie ma ona zastosowania do pracowników administracji publicznej lub instytucji prawa publicznego (lub - w przypadku gdy państwa członkowskie nie stosują tego pojęcia - do jednostek będących ich odpowiednikami). 
zaopiniowany przez Szefa Służby Cywilnej). Co ciekawe, ustawodawca w art. 15zzzzzr specustawy COVID-19 wprowadza personalną odpowiedzialność za skuteczność przeprowadzenia całego procesu osoby właściwej w danym podmiocie do dokonywania za pracodawcę czynności w sprawach z zakresu prawa pracy. Ponadto osoby te odpowiadają także za utrzymanie zatrudnienia na poziomie nie wyższym niż osiągnięty po przeprowadzonym zmniejszeniu zatrudnienia na czas określony w rozporządzeniu ${ }^{2}$. Ustawa wprowadza w stosunku do tych osób drobiazgowo opisane obowiązki informacyjne dotyczące sposobu realizacji działań wynikających z rozporządzenia Rady Ministrów, które jednak ze względu na swój administracyjny charakter nie będą szerzej omawiane.

Przed dokonaniem szczegółowej analizy należy wskazać, kogo mają dotyczyć działania, o których mowa w specustawie COVID-19. I tak rozwiązania te mają być realizowane w stosunku do osób zatrudnionych na podstawie stosunku pracy w Kancelarii Prezesa Rady Ministrów, urzędach obsługujących członków Rady Ministrów, urzędach obsługujących organy administracji rządowej w województwie, a także w jednostkach podległych i nadzorowanych przez prezesa Rady Ministrów, ministra kierującego działem administracji rządowej lub wojewodę ${ }^{3}$. Przewidywane w ustawie środki, za pomocą których można obniżyć koszty zatrudnienia (a nie - jak wskazano w ustawie - jedynie koszty wynagrodzeń osobowych), można podzielić na dwie grupy: zmniejszenie stanu zatrudnienia oraz zawieszenie stosowania niektórych uprawnień. Mechanizmy te są stosowane standardowo w procesach restrukturyzacji zatrudnienia i dlatego ich wybór nie budzi specjalnych wątpliwości, czego nie można jednak powiedzieć o mechanizmach ich wdrażania, co będzie przedmiotem dalszych rozważań.

\section{Zmniejszenie zatrudnienia}

\subsection{Założenia ogólne}

Jeżeli chodzi o zmniejszenie zatrudnienia, to pod tym pojęciem rozumie się zarówno rozwiązanie stosunków pracy, jak i zmniejszenie wymiaru czasu pracy ${ }^{4}$ Szczególnie

${ }^{2}$ Przy czym obowiązek ten nie dotyczy zwiększenia liczby etatów w związku z zakończeniem okresu, w którym pracownik miał obniżony wymiar czasu pracy na podstawie przepisów działu VIII ustawy z dnia 26 czerwca 1974 roku - Kodeks pracy (Dz.U. 2020, poz. 1320 tekst jedn., dalej: Kodeks pracy, k.p.), a więc opiekunów dzieci oraz pracowników, którzy podjęli pracę w wyniku przywrócenia do pracy przez sąd pracy.

${ }_{3}^{3}$ Należy równocześnie wskazać, że na mocy ustawy z dnia 19 czerwca 2020 roku o dopłatach do oprocentowania kredytów bankowych udzielanych przedsiębiorcom dotkniętym skutkami COVID-19 oraz o uproszczonym postępowaniu o zatwierdzenie układu w związku z wystąpieniem COVID-19 (Dz.U. 2020, poz. 1086) katalog ten rozszerzono również o jednostki sektora finansów publicznych, o których mowa w art. 9 pkt 5-9 ustawy z dnia 27 sierpnia 2009 roku o finansach publicznych (Dz.U. 2019, poz. 869 tekst jedn. ze zm.). Nie będą one jednak przedmiotem dalszych analiz.

${ }^{4}$ Takie samo rozumienie tego pojęcia znajdujemy między innymi w uchwale Sądu Najwyższego z dnia 16 marca 1994 roku, I PZP 7/94 (OSNAPiUS 1994, nr 2, poz. 25), która co prawda dotyczyła ustawy 
wątpliwa wydaje się jednoznaczna sugestia zawarta w art. 15zzzzzq specustawy COVID-19, że realizacja obowiązku zmniejszenia zatrudnienia może nastąpić przez rozwiązanie z pracownikiem stosunku pracy, w tym z pracownikiem posiadającym ustalone prawo do emerytury lub renty. Wydaje się, że taką redakcję tego przepisu można uznać wręcz za wytyczną, która na poziomie poszczególnych podmiotów może zostać potraktowana jako usprawiedliwienie bez konieczności zastanowienia się nad jej zasadnością. Co prawda, w dalszej części wskazuje się, że kryteria do zwolnienia nie będą miały charakteru dyskryminacyjnego, ale czy stwierdzenie to, które w świetle ogólnych standardów prawa pracy jest „oczywistą oczywistością”, będzie wystarczające, to dopiero czas pokaże.

Nie jest dla mnie do końca jasne, dlaczego w ustawie znalazł się drugi przykład sugerowanego rozstania z pracownikiem, jakim jest niezawarcie kolejnej umowy o pracę w przypadku umowy zawartej na okres próbny oraz na czas określony. Jak wiadomo, zgodnie z zasadą swobody umów pracownik nie ma roszczenia o nawiązanie kolejnej umowy o pracę po zakończeniu poprzedniego stosunku pracy, więc uregulowanie to wydaje się zbędne, nie mając w praktyce żadnego znaczenie normatywnego.

Ponieważ - jak wskazałem wyżej - cały proces restrukturyzacji w konkretnym podmiocie ma przeprowadzić osoba odpowiadająca za dokonywania czynności w sprawach z zakresu prawa pracy, to również ta osoba, zgodnie z ustawą, jest zobowiązana do opracowania kryteriów wyboru pracowników, które mają zastosowanie do zmniejszenia zatrudnienia. W praktyce jednak upoważnienie to jest fikcyjne, gdyż w art. 15 zzzzzp ust. 3 specustawy COVID-19 ustawodawca wprowadził wytyczne co do ustalenia tych kryteriów, dzieląc je na dwie zasadnicze grupy.

Do pierwszej kategorii należą kryteria podstawowe, które - jak wskazuje przepis są związane ze stosunkiem pracy i mają mieć charakter obiektywny, sprawiedliwy i niedyskryminujący (sformułowanie to nie ma w praktyce samo w sobie merytorycznego znaczenia, trudno sobie bowiem wyobrazić, żeby ustawodawca zakładał, że bez takiej wytycznej zwolnienia w administracji rządowej można by przeprowadzać bez tych reguł). Obejmują one w szczególności:

a) kwalifikacje zawodowe lub

b) umiejętności i doświadczenie zawodowe, lub

c) dotychczasowy przebieg pracy i stosunek do obowiązków pracowniczych, lub

d) przydatność pracownika do pracy, lub

e) dyspozycyjność pracownika w związku z potrzebą zapewnienia prawidłowego funkcjonowania podmiotu.

Kryteria te są na tyle ogólne i wyczerpujące, że trudno sobie wyobrazić, aby można było do nich wiele dodać na poziomie poszczególnych organizacji.

z dnia 28 grudnia 1989 roku o szczególnych zasadach rozwiązywania z pracownikami stosunków pracy z przyczyn dotyczących zakładu pracy oraz o zmianie niektórych ustaw (Dz.U. 2002, nr 112, poz. 980 tekst jedn. ze zm.), ale znajduje zastosowanie również pod rządami ZwolGrupU. 
Równocześnie ustawodawca przewidział również drugą grupę kryteriów, tak zwanych pomocniczych, służących ocenie zgodności z zasadami współżycia społecznego, w tym uwzględniających sytuację osobistą i rodzinną pracownika, w szczególności:

a) samotne wychowywanie dzieci lub

b) samotne utrzymywanie rodziny, lub

c) niepełnosprawność.

Uznając społeczną zasadność uwzględnienia również takich kryteriów ${ }^{5}$, należy zwrócić uwagę na praktyczną trudność związaną z ich wykorzystaniem w świetle obowiązujących przepisów o ochronie danych osobowych.

Mając na uwadze szczegółowość tych wytycznych, należałoby jednoznacznie wskazać, że są to kryteria bezwzględnie wiążące dla wszystkich podmiotów, do których skierowana jest ustawa (uszczegółowiona w rozporządzeniu), a nie jedynie wytyczne (jak to sugeruje specustawa COVID-19) dające swobodę w podejmowaniu decyzji na poziomie organizacji; tym bardziej że zgodnie z delegacją ustawową rozporządzenie ma określić wysokość procentowego wskaźnika zmniejszenia zatrudnienia (sposób przeprowadzenia kalkulacji zmniejszenia liczby etatów został szczegółowo opisany bezpośrednio w specustawie COVID-19), czas na realizację obowiązku zmniejszenia zatrudnienia oraz termin przedłożenia informacji o realizacji obowiązku zmniejszenia zatrudnienia (jak więc widać, ustawodawca zakłada, że proces ten będzie przebiegał bez specjalnych problemów, co wydaje się myśleniem dosyć optymistycznym). Informacje te, zgodnie z art. 15 zzzzzr ust. 4 specustawy COVID-19, wskazana wyżej osoba odpowiadająca za sprawy personalne podaje do wiadomości pracowników w sposób przyjęty w danym podmiocie. Jak jest zrozumiałe, że w analogicznych sytuacjach kwestie te nie są negocjowane z pracownikami, tak pojawia się pytanie o sens wynikającego z ust. 5 tego artykułu zarówno samego zawiadamiania na piśmie zakładowych organizacji związkowych - lub w przypadku ich braku przedstawicieli pracowników wyłonionych w trybie przyjętym w tej jednostce ${ }^{6}$ - o ustalonych kryteriach (a należy się spodziewać, że zostaną po prostu powielone $\mathrm{z}$ ustawy), proponowanym sposobie przeprowadzenia zmniejszenia zatrudnienia, w tym o liczbie pracowników, z którymi zamierza się rozwiązać stosunek pracy (liczbie już przesądzonej, jak wynika ze wskazanych wyżej przepisów), jak i oczekiwania na wydanie przez przedstawicielstwo pracowników, w terminie siedmiu dni od dnia otrzymania zawiadomienia, opinii dotyczącej proponowanego sposobu przeprowadzenia

${ }^{5} \mathrm{Na}$ co zwracano uwagę już od wielu lat, a czego najlepszym przykładem jest uchwała pełnego składu Izby Pracy i Ubezpieczeń Społecznych Sądu Najwyższego z dnia 27 czerwca 1985 roku w sprawie wytycznych dotyczących wykładni art. 45 Kodeksu pracy i praktyki sądowej stosowania tego przepisu w zakresie zasadności wypowiedzenia umowy o pracę (M.P. 1985, nr 24, poz. 192).

${ }^{6} \mathrm{~W}$ tym miejscu warto zadać pytanie, które pojawiło się również w kontekście zawierania porozumień z art. 15 g i 15 zf specustawy COVID-19, jak to zrobić, bo w praktyce takiego przedstawicielstwa najczęściej nie ma, a w przypadku pandemii może pojawić się problem z wdrożeniem stosownej procedury wyborczej. Dlatego zasadne wydaje się skorzystanie z postanowień zawartych we wskazanych wyżej przepisach, zgodnie z którymi w takiej sytuacji można by przekazać stosowne informacje przedstawicielom wybranym przez pracowników uprzednio w innych celach przewidzianych w przepisach prawa pracy. 
zmniejszenia zatrudnienia. Jest to więc w praktyce czysta fikcja, tym bardziej że ustawa nie wskazuje, co z taką opinią miałaby zrobić osoba odpowiadająca za sprawy personalne. W świetle całokształtu przepisów wydaje się, że nie tylko nie musi nic robić, ale też w zasadzie nie może, skoro również jej autonomia w tym zakresie jest iluzoryczna.

\subsection{Katalog osób „szczególnie chronionych”}

Specustawa COVID-19, podobnie jak ZwolGrupU, wskazuje, że przy wypowiadaniu pracownikom stosunków pracy nie stosuje się przepisów odrębnych dotyczących szczególnej ochrony pracowników przed wypowiedzeniem lub rozwiązaniem stosunku pracy oraz ustalających szczególne przesłanki lub warunki nawiązywania lub rozwiązywania stosunku pracy. Równocześnie jednak ta pierwsza ustawa wprowadziła dosyć obszerny katalog osób, które nie będą podlegały pod redukcję zatrudnienia. Przy tym część tych osób jest chroniona ze względu na pełnioną funkcję lub zajmowane stanowisko, specyficzne dla administracji, ochrona drugiej grupy opiera się zaś na przepisach powszechnych. I tak do pierwszej z tych grup zaliczono:

1) osoby zajmujące kierownicze stanowisko państwowe,

2) kierownika jednostki niebędącego osobą zajmującą kierownicze stanowisko państwowe,

3) dyrektora generalnego urzędu,

4) głównego księgowego jednostki, głównego księgowego części budżetowej, której dysponentem jest wojewoda, oraz głównego księgowego części budżetowej, której dysponentem jest minister albo kierownik urzędu centralnego,

5) audytora wewnętrznego jednostki,

6) pełnomocnika do spraw ochrony informacji niejawnych jednostki,

7) pracownika służby bezpieczeństwa i higieny pracy oraz pracownika zatrudnionego w jednostce przy innej pracy, któremu powierzono wykonywanie zadań tej służby,

8) pracowników finansowanych $\mathrm{w}$ ramach programów $\mathrm{z}$ udziałem środków, o których mowa w art. 5 ust. 1 pkt 2 i 3 ustawy z dnia 27 sierpnia 2009 roku o finansach publicznych (Dz.U. 2019, poz. 869 tekst jedn. ze zm.) ${ }^{7}$.

Jeżeli chodzi o drugą grupę osób szczególnie chronionych, to ich katalog jest zbliżony do zawartego w ZwolGrupU. I tak dotyczy on osób objętych ochroną wynikającą z działu VIII Kodeksu Pracy, z art. 32 ust. 1 pkt 1 ustawy z dnia 23 maja 1991 roku o związkach zawodowych (Dz.U. 2019, poz. 263 tekst jedn.), pracowników będących społecznymi inspektorami pracy, w okresie objęcia szczególną ochroną przed wypowiedzeniem lub rozwiązaniem stosunku pracy, a także - czego nie przewiduje ZwolGrupU - inspektorów ochrony danych osobowych. Dodatkowo przy wypowiadaniu pracownikom stosunków pracy stosuje się przepisy art. 39-41 k.p., przy czym w przypadku

${ }^{7}$ Chodzi tutaj o środki pochodzące z budżetu Unii Europejskiej, niepodlegające zwrotowi środki z pomocy udzielanej przez państwa członkowskie Europejskiego Porozumienia o Wolnym Handlu (EFTA) oraz środki pochodzące ze źródeł zagranicznych niepodlegające zwrotowi. 
osób korzystających z urlopów, a także w czasie innej usprawiedliwionej nieobecności pracownika w pracy, jeżeli nie upłynął jeszcze okres uprawniający do rozwiązania umowy o pracę bez wypowiedzenia stosunku pracy, wypowiedzenie jest dopuszczalne w czasie urlopu udzielonego na co najmniej trzy miesiące, a jeżeli upłynął już okres uprawniający pracodawcę do rozwiązania stosunku pracy bez wypowiedzenia - także $\mathrm{w}$ czasie innej usprawiedliwionej nieobecności pracownika w pracy. Wypowiedzenie pracownikowi warunków pracy i płacy jest zaś dopuszczalne niezależnie od okresu, na który urlop jest udzielony, lub okresu trwania innej usprawiedliwionej nieobecności pracownika w pracy.

\subsection{Skutki dla pracowników objęcia działaniami restrukturyzacyjnymi}

Osoby, które mogą podlegać działaniom restrukturyzacyjnym, w praktyce zostały pozbawione jakiejkolwiek ochrony, w art. 15zzzzzs specustawy COVID-19 wskazuje się bowiem, że objęcie pracownika, w tym urzędnika służby cywilnej oraz pracownika służby cywilnej, zmniejszeniem zatrudnienia stanowi samoistną podstawę do rozwiązania $\mathrm{z}$ nim stosunku pracy w drodze wypowiedzenia lub obniżenia wymiaru czasu pracy $\mathrm{z}$ jednoczesnym proporcjonalnym zmniejszeniem wynagrodzenia za pracę - a więc nie wymaga to uzasadnienia ${ }^{8}$. Co więcej, mimo iż - jak wskazałem wyżej przepisy nie przewidują wpływu związków zawodowych na same kryteria doboru do zwolnień (tym bardziej nie ma możliwości negocjowania świadczeń dla zwalnianych pracowników powyżej określonych w ustawie), to specustawa COVID-19 wyłącza jeszcze stosowanie art. 38 k.p., a więc nawet konsultację z partnerem społecznym zasadności rozwiązania stosunku pracy w odniesieniu do konkretnego pracownika (co jak wiadomo - w przypadku ZwolGrupU ma miejsce jedynie wówczas, gdy kryteria te zostały uzgodnione ze związkami zawodowymi). Jak być może można by uznać dopuszczalność takiego działania, biorąc pod uwagę szczególną sytuację związaną z pandemią koronawirusa i możliwość odwołania się przez pracownika do sądu, tak nie widzę żadnego racjonalnego uzasadnienia, dla którego ustawodawca nie przewidział, analogicznie jak jest to uregulowane w ZwolGrupU, pierwszeństwa pracowników zwolnionych $\mathrm{w}$ tym trybie $\mathrm{z}$ możliwości ponownego zatrudnienia $\mathrm{w}$ przypadku, gdyby po zakończeniu okresu oszczędności miało miejsce ponowne otwarcie procedur rekrutacyjnych. Brak takiej możliwości może świadczyć o tym, iż - jak wskazywałem wcześniej - celem tych przepisów jest również dokonanie wymiany kadr w administracji, co niekoniecznie jest zgodne z zawartym w ustawie założeniem zapewnienia prawidłowego realizowania zadań administracji rządowej.

\footnotetext{
${ }^{8}$ Nie ulega jednak, moim zdaniem, wątpliwości, że zasadność wskazania konkretnego pracownika do zwolnienia może być weryfikowana przez sąd chociażby na podstawie wymienionych wyżej kryteriów obiektywizmu, sprawiedliwości czy niedyskryminacji, co - jak wskazałem - może mieć szczególne znaczenie w przypadku osób posiadających już uprawnienia do emerytury.
} 
Niezależnie od tego, jakie przesłanki będą kierowały osobami decydującymi o polityce personalnej przy zwalnianiu pracowników, niezrozumiałe jest dla mnie również wyłączenie wynikającego zarówno z prawa europejskiego, jak i z ZwolGrupU obowiązku współpracy w trakcie procedury zwolnień z urzędami pracy. Celem tej współpracy, która w praktyce ogranicza się przecież do przekazania w odpowiednim czasie stosownych informacji, jest przygotowanie instytucji rynku pracy do konieczności aktywizacji osób, które zostaną pozbawione pracy, co w przypadku restrukturyzacji administracji rządowej może być szczególnie trudne. Należy bowiem zwrócić uwagę, że wiele z tych osób całe swoje życie zawodowe spędziła w sektorze budżetowym, który z punktu widzenia pracowników rządzi się zupełnie innymi prawami niż gospodarka rynkowa. Tymczasem skoro - jak wskazałem wyżej - nie planuje się ich ponownego zatrudnienia w administracji, to muszą one szukać pracy w często nieznanych im realiach, do których powinni zostać przygotowani właśnie przez urzędy pracy. Dlatego też uważam, że obowiązki nałożone w tym zakresie na pracodawców na mocy ZwolGrupU powinny również być wprowadzone w stosunku do pracowników zwalnianych $\mathrm{w}$ administracji rządowej. Uważam też, że właśnie ze względu na potencjalną trudność w znalezieniu zatrudnienia $\mathrm{w}$ stosunku do tych osób należałoby przewidzieć również jakieś specjalne programy, chociażby na wzór wynikających z art. 70 ustawy z dnia 20 kwietnia 2004 roku o promocji zatrudnienia i instytucjach rynku pracy (Dz.U. 2020, poz. 1409 tekst jedn.). Być może zostaną one wprowadzone w trakcie dalszych działań legislacyjnych, ale skoro ustawodawca tak szczegółowo określił procedurę samego wprowadzania programów restrukturyzacyjnych (wręcz z podaniem urzędników odpowiadających za ich wprowadzenie), to brak w specustawie COVID-19 tak istotnego i wiążącego się jednak z koniecznością wydatkowania środków publicznych narzędzia wspierającego zwalnianych pracowników wydaje się symptomatyczny.

W kontekście wskazanych wyżej uwag należy też ocenić kolejną regulację zawartą w specustawie COVID-19, zgodnie z którą złożenie pracownikowi oświadczenia o wypowiedzeniu stosunku pracy lub oświadczenia o wypowiedzeniu zmieniającym, którego istotą jest obniżenie wymiaru czasu pracy z jednoczesnym proporcjonalnym zmniejszeniem wynagrodzenia za pracę, lub innego oświadczenia o takim charakterze, może nastąpić nie wcześniej niż po upływie czternastu dni od dnia przekazania zawiadomienia związkom zawodowym lub przedstawicielstwu pracowników. Założenie odroczenia momentu wręczenia pracownikowi wypowiedzenia, a w konsekwencji również opóźnienia rozwiązania stosunku pracy, jest zgodne zarówno ze ZwolGrupU, jak i z dyrektywą 98/59. Jednakże odroczenie to jest powiązane z przekazaniem stosownych informacji urzędom pracy, które dzięki temu miałyby możliwość odpowiedniego przygotowania się do „przyjęcia” zwolnionych pracowników. W przypadku gdy to odroczenie nie wiąże się $\mathrm{z}$ informowaniem urzędu pracy, jego wprowadzenie nie ma, moim zdaniem, racji bytu.

Na koniec należy wskazać, że w przypadku zwolnienia pracowników specustawa COVID-19 przewiduje odprawę pieniężną, której wysokość i zasady przyznawania są analogiczne do wynikających z art. 8 ZwolGrupU. W praktyce jedyna różnica jest taka, 
że maksymalna wysokość odprawy, wynosząca piętnastokrotność minimalnego wynagrodzenia za pracę, nie może być podniesiona, tak jak może to mieć miejsce w przypadku negocjacji pracodawcy ze związkami zawodowymi na podstawie tej ostatniej ustawy.

\section{Czasowa zmiana warunków zatrudnienia}

\subsection{Założenia ogólne}

Drugą formą oszczędności przewidzianą w ustawie jest wprowadzenie mniej korzystnych warunków zatrudnienia pracowników niż wynikające z podstawy nawiązania stosunku pracy ${ }^{9}$, przy czym w odróżnieniu od wypowiedzenia umów o pracę działania te mogą być wprowadzane w stosunku do wszystkich pracowników podmiotu lub w grupach pracowników w zależności od podstawy nawiązania stosunku pracy.

Również w tym przypadku autonomia poszczególnych podmiotów jest bardzo ograniczona, Rada Ministrów w rozporządzeniu ma bowiem określić:

1) zakres wprowadzonych ograniczeń skutkujących mniej korzystnymi warunkami zatrudnienia pracowników niż wynikające z podstawy nawiązania stosunku pracy, w podziale na grupy pracowników, w zależności od podstawy nawiązania stosunku pracy;

2) okres obowiązywania wprowadzonych ograniczeń, nie dłuższy niż do końca danego roku budżetowego, z uwzględnieniem aktualnej sytuacji finansów publicznych, sytuacji społeczno-gospodarczej (a więc znowu pojawiają się określenia nieostre, które sprawiają, że Rada Ministrów ma możliwość stosowania tego narzędzia w bliżej niedookreślonym czasie) oraz potrzeb zapewnienia sprawnej realizacji zadań podmiotu, z poszanowaniem zasad równości i niedyskryminacji (te dwa ostatnie sformułowania w praktyce nie mają bezpośredniej żadnej dodatkowej wartości, gdyż - jak wskazałem wyżej - obowiązek ich stosowania wynika $\mathrm{z}$ ogólnych zasad prawa pracy);

3) termin przedłożenia informacji o realizacji obowiązku zmiany warunków zatrudnienia oraz o liczbie osób, które nie wyraziły zgody na zmianę warunków zatrudnienia (eufemistycznie nazwanego w ustawie „zastosowaniem ograniczeń”).

\subsection{Skutki dla pracowników}

Zgodnie z art. 15zzzzzu specustawy COVID-19 wskazane wyżej ograniczenia mogą polegać na zawieszeniu prawa do dodatkowych składników wynagrodzeń, nagród, premii

9 Jest to uregulowanie analogiczne do wynikającego z art. 9(1) i 241(27) k.p. zawieszenia stosowania postanowień prawa zakładowego (a więc zarówno układów zbiorowych pracy, jak i regulaminów) oraz wynikającego $z$ art. 23(1a) tego samego aktu, a także $z$ art. 15zf ust. 1 pkt 3 specustawy COVID-19 zawieszenia stosowania postanowień umów o pracę. Przy tym, co należy jednoznacznie podkreślić, wszystkie te zawieszenia wymagają uzgodnienia z przedstawicielstwem pracowników, czego nie przewidują przepisy dotyczące restrukturyzacji zatrudnienia w administracji rządowej. 
i innych świadczeń o takim charakterze lub zawieszeniu uprawnień wynikających z innych przepisów, w tym prawa do dodatkowego urlopu, przy czym w czasie obowiązywania tych ograniczeń nie stosuje się przepisów stanowiących podstawę do przyznawania zawieszonych składników wynagrodzeń, świadczeń lub uprawnien ${ }^{10}$.

Osoba właściwa $\mathrm{w}$ danym podmiocie do dokonywania za pracodawcę czynności $\mathrm{w}$ sprawach z zakresu prawa pracy informuje pisemnie pracownika o wprowadzonych ograniczeniach. W odróżnieniu od przepisów zawartych w Kodeksie pracy, wedle których zawieszenie stosowania uprawnień jest nienegocjowalne, w przypadku specustawy COVID-19 pracownik w terminie czternastu dni od dnia otrzymania tego zawiadomienia może złożyć oświadczenie o braku zgody na zastosowanie wobec niego ograniczeń. Oświadczenie to jest równoznaczne ze złożeniem przez pracownika oświadczenia o rozwiązaniu stosunku pracy za wypowiedzeniem.

\section{Podsumowanie}

Ocena będącej przedmiotem niniejszego opracowania regulacji jest generalnie negatywna, mimo iż - jak wskazałem we wprowadzeniu - cel jej wydania jest jak najbardziej zrozumiały. I tak jak zostało to, mam nadzieję, wykazane, w wielu miejscach zawiera ona postanowienia zbędne, a przez to utrudniające zrozumienie prawdziwych intencji ustawodawcy. Główny zarzut dotyczy fikcyjności założenia, że na poziomie poszczególnych organizacji istnieje możliwość przeprowadzenia autonomicznych procesów restrukturyzacyjnych, skoro wszystkie merytoryczne decyzje wynikają bezpośrednio z prawa powszechnego, a więc specustawy COVID-19 doprecyzowanej w rozporządzeniu Rady Ministrów. Dotyczy to zwłaszcza upoważnienia osoby odpowiadającej za sprawy personalne w organizacji do określenia kryteriów zwolnień, chociaż zostały one już przesądzone na wyższym szczeblu. W związku z powyższym fikcją jest też opiniowanie przez partnera społecznego zasad całego procesu, który w zasadzie również nie zależy od wskazanej wyżej osoby odpowiadającej za sprawy personalne. Wreszcie wyłączenie przedstawicielstwa pracowników od wpływu na określenie kryteriów zwolnień $\mathrm{w}$ powiązaniu $\mathrm{z}$ wyłączeniem możliwości konsultacji ze związkami zawodowymi indywidualnych wypowiedzeń, a nawet brak konieczności uzasadnienia zwolnienia $\mathrm{w}$ dokumencie wypowiadającym umowę o pracę oznaczają, że pojawia się duże ryzyko arbitralności podejmowanych decyzji. Dotyczy to zwłaszcza zawartej w specustawie COVID-19 sugestii co do możliwości zwolnienia pracowników z samego faktu, że posiadają już uprawnienia emerytalne. Krytycznie należy też odnieść się do niewłączenia urzędów pracy w proces restrukturyzacji zatrudnienia. Można jedynie wyrazić nadzieję, że w momencie kiedy już proces ten zostanie uruchomiony (bo co do tego raczej nie

${ }^{10}$ Należy podkreślić, że w przypadku wskazanych wyżej uregulowań z Kodeksu pracy istnieje trzyletni maksymalny okres stosowania tej instytucji. Natomiast analogiczny przepis art. $15 z f$ ust. 1 pkt 3 specustawy COVID-19, podobnie jak wyżej omawiany, nie przewiduje limitu czasowego. 
mam wątpliwości), ustawodawca pomyśli również o wsparciu dla zwalnianych pracowników, dla których często przejście do pracy w sektorze prywatnym może być wielkim wyzwaniem. Mam też nadzieję, że wyrażone w niniejszym opracowaniu uwagi krytyczne nie sprawdzą się i jeżeli już dojdzie do faktycznej konieczności wprowadzenia procesów oszczędnościowych w administracji rządowej, będą one realizowane zgodnie z deklaracją zawartą w ustawie w sposób obiektywny, sprawiedliwy i niedyskryminacyjny, a równocześnie nie odbije się to negatywnie na funkcjonowaniu organów państwa.

\section{Orzecznictwo}

Uchwała pełnego składu Izby Pracy i Ubezpieczeń Społecznych Sądu Najwyższego z dnia 27 czerwca 1985 roku w sprawie wytycznych dotyczących wykładni art. 45 Kodeksu pracy i praktyki sądowej stosowania tego przepisu w zakresie zasadności wypowiedzenia umowy o pracę, M.P. 1985, nr 24, poz. 192.

Uchwała Sądu Najwyższego z dnia 16 marca 1994 roku, I PZP 7/94, OSNAPiUS 1994, nr 2, poz. 25.

\section{Akty prawa międzynarodowego}

Dyrektywa 98/59/WE z dnia 20 lipca 1998 roku w sprawie zbliżenia ustawodawstw państw członkowskich odnoszących się do zwolnień grupowych, Dz.Urz. WE L 1998, nr 225.

\section{Akty prawa krajowego}

Ustawa z dnia 26 czerwca 1974 roku - Kodeks pracy, Dz.U. 2020, poz. 1320 tekst jedn.

Ustawa z dnia 28 grudnia 1989 roku o szczególnych zasadach rozwiązywania z pracownikami stosunków pracy z przyczyn dotyczących zakładu pracy oraz o zmianie niektórych ustaw, Dz.U. 2002, nr 112, poz. 980 tekst jedn. ze zm.

Ustawa z dnia 23 maja 1991 roku o związkach zawodowych, Dz.U. 2019, poz. 263 tekst jedn. Ustawa z dnia 13 marca 2003 roku o szczególnych zasadach rozwiązywania z pracownikami stosunków pracy z przyczyn niedotyczących pracowników, Dz.U. 2018, poz. 1969 tekst jedn.

Ustawa z dnia 20 kwietnia 2004 roku o promocji zatrudnienia i instytucjach rynku pracy, Dz.U. 2020, poz. 1409 tekst jedn.

Ustawa z dnia 27 sierpnia 2009 roku o finansach publicznych, Dz.U. 2019, poz. 869 tekst jedn. ze zm.

Ustawa z dnia 2 marca 2020 roku o szczególnych rozwiązaniach związanych z zapobieganiem, przeciwdziałaniem i zwalczaniem COVID-19, innych chorób zakaźnych oraz wywołanych nimi sytuacji kryzysowych, Dz.U. 2020, poz. 374 ze zm.

Ustawa z dnia 16 kwietnia 2020 roku o szczególnych instrumentach wsparcia w związku z rozprzestrzenianiem się wirusa SARS-CoV-2, Dz.U. 2020, poz. 695 ze zm. 
Ustawa z dnia 19 czerwca 2020 roku o dopłatach do oprocentowania kredytów bankowych udzielanych przedsiębiorcom dotkniętym skutkami COVID-19 oraz o uproszczonym postępowaniu o zatwierdzenie układu w związku z wystąpieniem COVID-19, Dz.U 2020, poz. 1086. 